\title{
Pretending not to be Alan Schoenfeld
}

\author{
Sanjoy Mahajan \\ Cavendish Laboratory, Astrophysics, Cambridge CB3 OHE, UK, sanjoy@mrao.cam.ac.uk
}

\begin{abstract}
I opened my big mouth and suggested that we invite Alan Schoenfeld to talk about mathematics education. He couldn't come to Rochester so the organizers (names concealed to protect the guilty) foolishly asked me to talk. Health warning: You get what you pay for.
\end{abstract}

Bookstores stock myriad books on popular physics but hardly any on popular mathematics: Americans learn (to hate) mathematics for twelve years but physics for at most one year, which is not enough time to kill all curiosity.

In one study, ninth-grade students (for non-US readers: roughly age 14) were asked: The distance from Boston to Portland [Maine] by water is 120 miles. Three steamers leave Boston, simultaneously, for Portland. One makes the trip in 10 hours, one in 12, and one in 15. How long will it be before all 3 reach Portland? Only 6 out of 29 students answered correctly (Benezet 1936). I can guess what answer they gave. As Stella Baruk (1985, p. 25, my translation) explains: 'Among the Grenoble professors of mathematics education working on elementary teaching, one thought to ask 8-year-old pupils the following problem: There are 26 sheep and 10 goats on a ship. How old is the captain? Now, of the 97 pupils asked, 76 answered by simply combining the numbers in the problem.' The damage begins early.

And that's the good news. Radatz, cited in Schoenfeld (1989), inserted non-problems into sets of problems worked by school children. For example: Mr. Lorenz and 3 colleagues started at Bielefeld at 9 a.m. and drove the $360 \mathrm{~km}$ to Frankfurt, with a rest stop of 30 minutes. The percentage of students who answer such non-questions increased consistently from kindergarten through 6th grade.

Traditional education works. In January 1971, the US population was polled whether the United States should withdraw its troops from Vietnam (Loewen 1995, pp. 302-311). The percentages of hawks (against withdrawal) and doves (for withdrawal), broken down by highest level of education, are:

\begin{tabular}{lcc}
\hline & Withdraw & Stay \\
\hline College & 60 & 40 \\
High school & 75 & 25 \\
Grade school & 80 & 20 \\
Overall & 73 & 27 \\
\hline
\end{tabular}

Educated people think that education makes us more tolerant and able to detect bad arguments, like those used to support the war. Whereas education does the opposite while making us believe that it makes us discerning - so we condemn yesterday's wars and support today's.

Mathematics education shares the blame with other subjects and institutions. I'll briefly discuss two mathematics teaching experiments that taught students to think. This introduction was an attempt to scare the hell out of you. The subtle material that follows is designed to lure you into reading the most interesting works and stealing the ideas for physics teaching.

\section{Benezet}

Louis Benezet's experiment was the most radical. As superintendent of schools in Manchester, New Hampshire, Benezet saw the results of standard mathematics teaching: 'For some years I had noted that the effect of the early introduction of arithmetic had been to dull and almost chloroform the child's reasoning faculties' (Benezet 1935a). 
A strong, and probably difficult, personality, Benezet took his own advice and abolished formal arithmetic teaching until grade 6 or 7 . Instead children 'reported on books that they had read, on incidents which they had seen, on visits that they had made. They told the stories of movies that they had attended and they made up romances on the spur of the moment.' As you can see from the detailed curriculum in Benezet (1935b), students learnt plenty of arithmetic but only in context. Most importantly, they learnt estimation and number sense - they made friends with numbers.

Some parents screamed bloody murder. One former student told me (in an email on 5 August 2001): 'My father being educated in Ireland was appalled at his actions and I still can hear him swearing that Louis P. was a heretic.' The screaming would have been louder except that Benezet headed off much trouble by doing the experiment in schools where "not one parent in ten spoke English as his mother tongue', otherwise 'I would have had a storm of protest and the experiment would never have been tried' (Benezet 1935a). This inertia of the privileged is eternal: See Kohn (1998).

Even so the storm waves were high. So Benezet devised qualitative and quantitative tests show the success of his program. He devised questions like the one about the three steamers leaving for Portland. Among the normally taught ninth graders, 6 out of 29 got it right. The second graders in the experimental classrooms had 'an almost perfect score' (Benezet 1936). With a stenographer, he visited classrooms and asked students to express mathematical ideas in their own words; the experimental classes were far more articulate and coherent (Benezet 1936). Etta Berman, one of the teachers in the program, studied it for a masters degree (1935); she gave a battery of quantitative tests to 106 control and 82 experimental students in the sixth grade. She concluded, with commendable understatement: 'The results of this study cast doubt upon whether we are justified in devoting five years to the drilling of formal arithmetic' (Berman 1935, p. 40).

Despite or because of these results, in 1936 the Manchester school board ended the experiment. Two years later Benezet was forced out of his job, and today few know of his experiment. Second health warning: No good deed goes unpunished.

\section{Schoenfeld}

I won't discuss Schoenfeld's excellent work, which is widely available and known (see the bibliography). Instead I want to talk about another little-known experiment to which Schoenfeld (1991) introduced me.

\section{Fawcett}

Harold Fawcett, a mathematics teacher at the Ohio State experimental high school, noted that everyone hails critical thinking and that mathematics teachers say, yes we agree, that's why we teach proof (Fawcett 1938, p. 1). But these 'large general objectives' get only lip service: '...[t]he major emphasis is placed on a body of theorems to be learned rather than on the method by which these theorems are established'. Does this pattern sound familiar from physics teaching? The results are also familiar: 'The pupil feels that these theorems are important in themselves and in his earnest effort to "know" them he resorts to memorization.'

Instead Fawcett's students each developed his or her own textbook. They argued and agreed what geometric ideas were fundamental, leaving them undefined, and developed definitions of other terms. Instead of theorems to prove, they were given a figure and asked, for example, 'What properties of this figure can you discover and establish by deductive proof?' (p. 91). The students transferred their skills by studying proof, and disproof, as they analyzed advertisements, legislative bills, and newspaper 
articles (pp. 75ff). In one example, they were asked about the Declaration of Independence (Jefferson 1776): 'What are the assumptions to which the fifty-six men who signed this document agreed?' and 'What conclusions are reached? Are these conclusions consistent with the assumptions?'

With this unorthodox method the students learnt plenty of geometry. On the Ohio Every Pupil Test in plane geometry, the average score of Fawcett's class was between the 80th and 90th percentiles (p. 102). They also learnt to think. One mother wrote that her daughter "may carry her criticism to the point of quibbling, however. In some cases she has gone to the point of criticising authorities about which she knew nothing' (p. 109). No wonder the course is so little known today.

\section{What did the students think?}

Fawcett quotes many student comments: 'I have not only learned how to prove theorems but also to think critically and analytically about everything in my life...[i]n this class I have learned things that I will never forget and will use in all areas all my life' (Fawcett 1938, p. 113). The student was prescient. The class described their contemporaneous reactions in their own book, Were We Guinea Pigs? (Class of 1938) and in interviews with Margaret Willis (1961). Fred Flener (2001) has been searching for and interviewing these guinea pigs, now over 60 years past the course. Many still consider it the best course they ever took, in school or college. Elaine Bucher Lyons told Flener: 'It was the depression, my parents were divorced, I had much less money than most of the other students at the University School, but I can say without a doubt, it was the happiest time of my life.'

Benezet describes his visits to the classrooms:

In the traditional fourth grades when I asked children to tell me what they had been reading...I could not find a single child who would admit that he had committed the sin of reading...In the four experimental fourth grades the children fairly fought for a chance to tell me what they had been reading. The hour closed, in each case, with a dozen hands waving in the air and little faces crestfallen, because we had not gotten around to hear what they had to tell. (Benezet 1935a)

Let's make physics course as inspiring!

\section{Bibliography}

I've combined the regular references with my list of favorites (there's lots of overlap), marking the favorites with an asterisk. Happy reading!

Baruk, S. (1985). L'Âge du Capitaine: De L'Erreur en Mathematiques. Editions du Seuil, Paris.

*Benezet, L.P. (1935, 1936). The Teaching of Arithmetic I, II, III: The Story of an Experiment. Journal of the National Education Association 24(8): 241-244 (1935); 24(9): 301-303 (1935); 25(1): 7-8 (1936). The articles (a) were reprinted in the Humanistic Mathematics Newsletter 6: 2-14 (May 1991); (b) are on the web along with other Benezetia at the Benezet Centre 〈http://wol.ra.phy.cam.ac.uk/sanjoy/benezet/〉.

*Berman, E. (1935). The Result of Deferring Systematic Teaching of Arithmetic to Grade Six as Disclosed by the Deferred Formal Arithmetic Plan at Manchester, New Hampshire. Masters Thesis, Boston University, USA.

*Brown, S.I. and M.I. Walter (1990). The Art of Problem Posing. Lawrence Erlbaum.

Class of 1938, University High School, The Ohio State University (1938). Were We Guinea Pigs?. Henry Holt.

*deGroot, A. (1965). Thought and Choice in Chess. Mouton. Profound protocol-analysis study of the differences between experts and novices. 
*Fawcett, H.P. (1938). The Nature of Proof: A Description and Evaluation of Certain Procedures Used in a Senior High School to Develop an Understanding of the Nature of Proof. Teachers' College Press. It was the 1938 Yearbook of the National Council of Teachers of Mathematics $\langle$ http: / / www. nctm.org $\rangle$ and is now available from them as H.P. Fawcett, The Thirteenth Yearbook: The Nature of Proof, 1995.

*Flener, F. (2001). A Geometry course that changed their lives: The guinea pigs after 60 years. Talk given April 6 at the NCTM Annual Conference. Available at $\langle$ http://groups . yahoo. com/group/math-learn) in the 'Files' section (you first have to join the group).

Kohn, A. (1998). Only for my kid: How privileged parents undermine school reform. Phi Delta Kappan 79(8): 568-577.

Jefferson, T. (1776). You don't expect a reference for this do you?!

*Lakatos, I. (1977). Proofs and Refutations, revised edition. Cambridge University Press.

Loewen, J.W. (1995). Lies My Teacher Told Me: Everything Your American History Textbook Got Wrong. New Press.

*Ma, L. (1999). Knowing and Teaching Elementary Mathematics: Teachers' Understanding of Fundamental Mathematics in China and the United States. Lawrence Erlbaum. For a review of see R. Askey, American Educator, Fall 1999; on the web at the back-to-basics site 'Mathematically Correct' 〈http: / / ourworld. compuserve.com/homepages/mathman/〉.

*Polya, G. (1954). Mathematics and Plausible Reasoning. Volume 1: Induction and Analogy in Mathematics; Volume 2: Patterns of Plausible Inference. Princeton University Press. The successors to his How to Solve It - but even more interesting and at a higher mathematical level.

*Polya, G. (1962, 1965, 1981). Mathematical Discovery: On Understanding, Learning, and Teaching Problem Solving, 2 volumes (volume 1, 1962; volume 2, 1965; combined edition, 1981). Wiley. Based on his courses at Stanford for mathematics teachers.

*Reusser, K. (1988). Problem solving beyond the logic of things: Contextual effects on understanding and solving word problems. Instructional Science 17: 309-338.

*Schoenfeld, A.H. (1985). Mathematical Problem Solving. Academic Press. Not for the casual but a treasure of information and ideas.

*Schoenfeld, A.H. (1987). What's all the fuss about metacognition? In A. Schoenfeld, ed., Cognitive Science and Mathematics Education, Lawrence Erlbaum.

*Schoenfeld, A.H. (1989). Teaching mathematical thinking and problem solving. In Lauren B. Resnick and Leonard B. Klopfer, eds., Toward the thinking curriculum: Current cognitive research, Association for Supervision and Curriculum Development [ASCD], Alexandria, VA.

*Schoenfeld, A.H. (1991). On Mathematics as sense-making: An informal attack on the unfortunate divorce of formal and informal mathematics. In J.F. Voss, D.N. Perkins, and J.W. Segal, eds., Informal Reasoning and Education, Lawrence Erlbaum, pp. 311-344.

*Schoenfeld, A.H. (1992). Learning to think mathematically: Problem solving, metacognition, and sense making in mathematics. In D.A. Grouws, ed., Handbook of Research on Mathematics Teaching and Learning, Macmillan, pp. 334-370. See also Schoenfeld's web site $\langle$ http://www-gse.berkeley.edu/Faculty/aschoenfeld $\rangle$ for this paper and more recent work.

*Wertheimer, M. (1945/1959). Productive Thinking, enlarged edition. Harper and Row. Classic of Gestalt psychology; fascinating examples and discussion of what we now call rote learning.

*Whitney, H. (1987). Coming alive in school math and beyond. Educational Studies in Mathematics 18(3): 229-242. Whitney, a famous topologist, got interested in school mathematics teaching towards the end of his life, and was inspired by Benezet's work $(1935,1936)$.

Willis, M. (1961). The Guinea Pigs after Twenty Years: A Follow-Up Study of the Class of 1938 of the University School, Ohio State. Ohio State University Press. 